$<$ 原 著 $>$

\title{
原発性肝癌の診断における 造影剤併用超音波検査の有用性の検討
}

$\begin{array}{lrllllll}\text { 鈴木 } & \text { 都男 } & \text { 山本 } & \text { 守敏 } & \text { 白畠 } & \text { 伸宏 } & \text { 倉繁 } & \text { 奈緒 } \\ \text { 西山 } & \text { 範 } & \text { 新井 } & \text { 敬一 } & \text { 山田 } & \text { 幸則 } & \text { 伊藤 } & \text { 敏文 } \\ \text { 増田 } & \text { 栄治 } & \text { 吉原 } & \text { 治正 } & \text { 鎌田 } & \text { 武信 } & & \end{array}$

要 旨：超音波造影剤レボビスト®の肝癌診療における有用性を検討した。パワードプラ法に 造影剂を使用することによって明らかに朋癌の血流シグナルの検出感度が向上し，ダイナミッ ク CT と同等の結果であった。特に体深部での検出率が向上し，レボビストは有用であると考 えられた。さらに，造影剤を使用した新しい血流検出法として造影ハーモニックパワードプラ 法(CHPD)の肝癌における血流シグナル検出能の検討も行った. CHPD の感度はダイナミッ ク CT 以上であった. CHPDでみられた肝癌の血流パターンを vascular pattern と diffuse pattern に分類した検討では血流パターンは分化度と密接に関係しており, vascular pattern を呈するものは高分化の肝癌に多くみられた。レボビストを使用した超音波検査は肝癌の診療 に有用であると考えられた。

索引用語： 超音波造影剤 肝細胞癌 超音波パワードプラ法 超音波造影ハーモニックパワードプラ法

\section{目的}

原発性肝細胞癌(以下，肝癌)の診療においては肝癌 に特異的な血行動態を捉えることが非常に重要な意味 を持っている. 古典的肝癌においては, 門脈からの血 行はみられず, 肝動脈による血流支配を受ける hypervascular な腫崵であることが知られ，画像診断 に利用されている.一方, 初期の高分化型肝癌におい ては動脈性腫瘍血管の増加はまだみられないが，腫瘍 の増大, 分化度の低下に伴って動脈性腫瘍血管が増加 し, hypervascular に変化してくる1).このような血 行動態の変化は肝癌の分化度を画像診断によって推定 するのに利用されている。 また, 肝癌の一般的な治療 法である経皮的エ夕ノール注入療法 (percutaneous ethanol injection therapy, PEIT) や経カテーテル的 肝動脈塞栓術 (transcatheter arterial embolization, TAE) の治療効果判定においては画像診断により血流 が残存するかどうかを判断することが一般的となって いる.

大阪労災病院消化器内科

$<$ 受付日2001年 2 月19日 $>$
従来, 肝癌の診療における血行動態の把握にはダイ ナミック CT や血管造影検查が一般的であった。超音 波検査による血流評価はカラードプラ法やパワードプ ラ法により可能とはなったものの，超音波の減衰する 体深部の腫愓などにおいて感度が劣ることが指摘され てきた2)。近年, 超音波造影剂レボビスト®の臨床応 用が可能となり, 血流検出の感度向上が期待されてい る.この超音波造影剤の本体は微小気泡であり，これ が超音波を強く反射することを利用するものである. さらに，超音波造影剤を用いた血流検出感度向上のた めの手法として造影ハーモニックパワードプラ法 (contrast harmonic power Doppler, 以下 CHPD)を 使った血流検出法が開発された。これは低い送信周波 数で強いパワーの超音波を照射して血管内の造影剂の 微小気泡を破壊し，それより得られる二次高調波(八 ーモニック)成分をドプラ信号として受信するもので ある。微小気泡の破壊により得られる信号は強度が大 きく, ハーモニック成分に富むことが知られてい る3).さらに, 微小気泡の破壊に伴う強いエコ一信号 の放出と, それまで存在していた気泡からの信号の急 激な消失が起こり,これはドプラシフトとして検出さ 
れる。これは “pseudo-Doppler”効果とも呼ばれる4) が，ほとんど流速のない血液からの信号でも検出可能 である5)。今回我々は，超音波造影剂を従来のパワー ドプラ法に使用した際の血流検出能の向上と, CHPD に使用した際の血流検出能を検討した。

\section{方 法}

\section{I＼cjkstart従来のパワードプラ法に超音波造影剤を使用した 際の感度向上についての検討}

対象は慢性肝疾患の経過観察中にエコーやCT など にて発見された肝癌 16 症例計 17 結節で, 腫瘍径は 10-60 mm, 平均径は 20.5 $13.7 \mathrm{~mm}$ である. 超音 波診断装置はアロカSSD-5500 で，3.5 MHz のコン ベックス型プローブを用い，2.5 MHz の周波数でパ ワードプラ法を行った。パルス繰り返し周波数は 650 $\mathrm{Hz}$ に, カラーゲインはノイズが出ない範囲内で最大 に設定した。造影剂投与前後における肝癌の血流を評 価し, 血流検出感度の向上を検討した。腫瘍中心部へ 向かう拍動流が観察されるものを血流シグナル陽性と 判定した。

造影剤はレボビスト®を使用した。レボビスト®は ガラクトースとパルミチン酸の $999: 1$ 混合物であり, 水に加えて懸濁させることにより微小気泡が形成され る.この気泡は赤血球よりも小さいため, 末梢静脈か らの投与でも右心系, 肺循環をこえて動脈系に流入し たのち全身に分布して超音波造影効果をあらわすこと が知られている6). まず通常のパワードプラ法にて腫 瘍の血流を観察したのち, レボビスト ${ }^{\circledR}(300 \mathrm{mg} / \mathrm{ml})$ $5 \mathrm{~m} l$ を注入速度 $1 \mathrm{ml} / 10 \mathrm{sec}$ にて注入し, 直後より パワードプラ法にて血流を観察した。ささらに，ほぼ同 時期に施行したダイナミック CT と比較して造影剤に よる血流検出能の向上を検討した. ダイナミック CT は造影剂を急速静注して早期相で high density を示 したもの, すなわち early enhancement が認められ る腫瘍を血流シグナル陽性と判定した。

\section{CHPD の有用性の検討}

対象はエコーやCT の画像診断にて肝内腫瘤性病変 を指摘されて造影超音波検査を行った症例で, 画像診 断や組織学的検討にて診断が確定している肝癌症例 29 症例 32 結節 (径 10-60 mm, 平均 $19.5 \pm 10.7 \mathrm{~mm}$ ) で ある。超音波診断装置は同様にアロカ SSD-5500を使 用し, mechanical index 1.1-1.4, 送信周波数 1.88 $\mathrm{MHz}$ ，受信周波数 $3.75 \mathrm{MHz}$ を用いた.

1. CHPD による肝癌の血流検出感度向上の検討 まず通常のパワードプラ法での観察を行った後,
CHPDにて観察した. パルス繰り返し周波数は 3.2 $\mathrm{kHz}$ に，カラーグインはノイズが出ない範囲内で最 大に設定した。造影剤はレボビスト ${ }^{\circledR}(300 \mathrm{mg} / \mathrm{m} l) 3$ $\mathrm{m} l$ を bolus で静注し, 注入後 10-60 秒の早期相を 中心に観察した。観察時間の前半は連続送信にて血管 のシグナルを中心に観察し, 後半は間欠送信(概ね 0.3-2.0 秒毎)を用いて実質の染影を中心に観察し た.この際の間欠送信の間隔は, 肝内の血管は明瞭に 認められるが，肝実質の染影としては認められない, すなわち肝全体が血流信号で埋まることのないような 範囲内でなるべく間隔を大きくして (最大で 5 秒 $)$, 腫 瘍内の血流をよく捉えられるように調節した。間欠送 信での観察にて, 腫瘍内部に血流シグナルが認められ るものを血流シグナル陽性と判定した。CHPDの間 欠送信時における血流パターンは大別して 2 つに分類 された. Fig. $1 \mathrm{a}$ (矢印)のごとく, 間欠送信時におい ても実質の染影が認められず，腫瘍中心にむかって周 囲から流入する血管と考えられる血流シグナルのみが 認められるものを vascular pattern (Fig. 1 b) とし た. 一方, Fig. $1 \mathrm{c}$ (矢印)のごとく, 腫場全体に血流 シグナルがびまん性に認められ，一本ずつの血管とし て同定できないものを diffuse pattern (Fig. 1d)とし た。ほほ同時期に行ったダイナミック CT による血流 評価と対比して CHPD の有用性を検討した。ダイナ ミック CT では造影剤の急速静注後, 早期相でhigh density を示したもの, すなわち early enhancement を示したものを血流シグナル陽性と判定した.

2. CHPD の血流パターンと肝癌の病理学的所見との 対比

肝癌の増大, 分化度の低下に伴って起こる血行動態 の変化を CHPD で検出可能であるかについての検討 を行った。対象は CHPD, ダイナミック CT を行い, その後の腫場の外科的切除, あるいは腫場生検によっ て組織学的検討が可能であった肝癌症例16例(径 11$31 \mathrm{~mm}$, 平均 $17.5 \pm 4.9 \mathrm{~mm}$ ) である. 肝癌の分化度 は高分化, 中分化, 低分化に分類し, 分化度と CHPD の血流パターンの関係を検討した。

\section{結果}

\section{I 従来のパワードプラ法に超音波造影剤を使用した 際の感度向上についての検討}

造影剂を使用することによってパワードプラ法の感 度は明瞭に向上した.レボビスト®使用前には指摘で きなかった微小な血流シグナルがレボビスト ${ }^{\circledR}$ 投与後 に観察可能となった Fig. 2). 結果のまとめを Table 

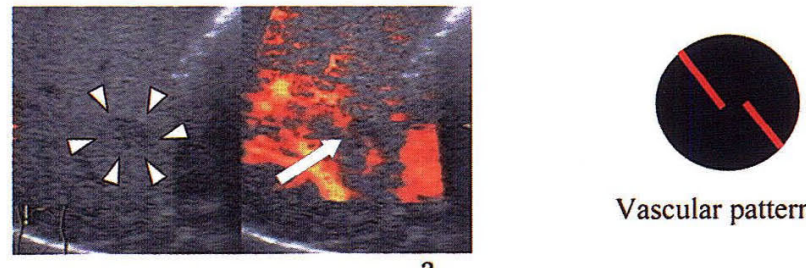

\section{Vascular pattern}

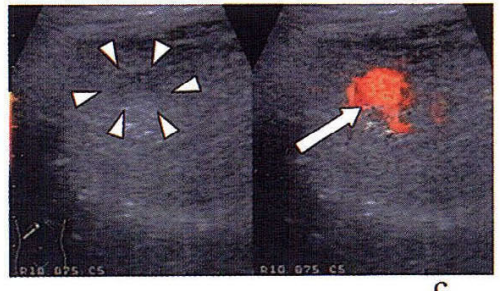

b

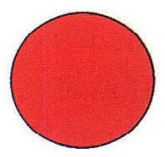

Diffuse pattern

Fig. 1 Contrast harmonic power Doppler (CHPD) study of representative cases of HCC. Gray-scale US image shows a hypoechoic mass in the liver (1a left, arrowheads). CHPD image shows segmental blood flow signals coursing to the tumor center (1a right, arrow). This blood flow pattern was classified as "vascular pattern"(1b). In another case of HCC, gray-scale US image also shows a hepatic hypocchoic mass (1c left, arrowheads). CHPD image shows diffuse signal in this tumor (1c right, arrow). This blood flow pattern was classified as "diffuse pattern"(1d).

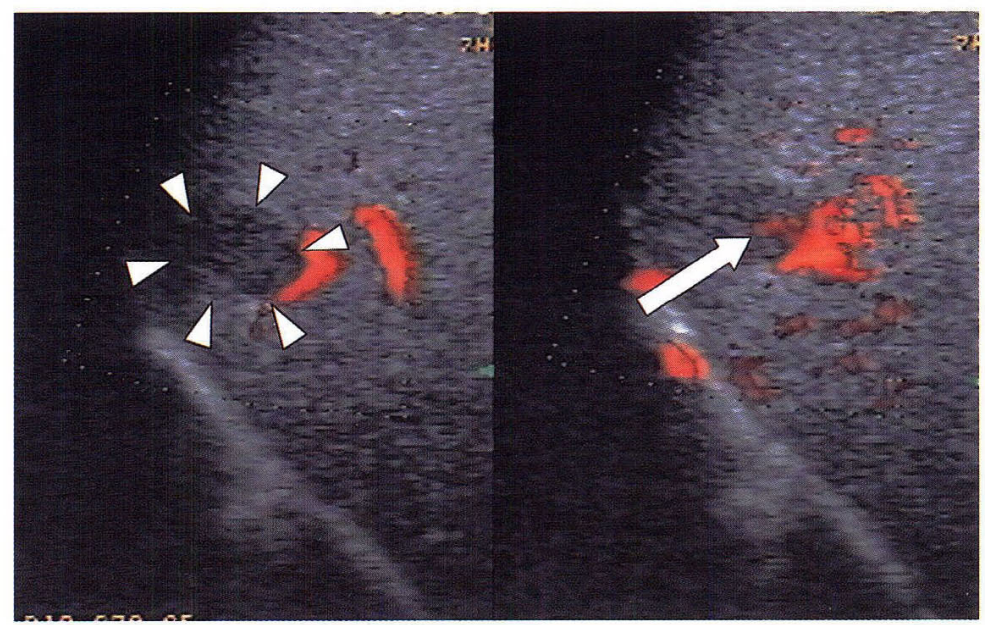

Fig. 2 Conventional power Doppler image before injection of the contrast agent can't reveal blood flow signal in the hypoechoic HCC (arrowheads) in the liver (left). After injection of the contrast agent, blood flow signal (arrow) is clearly observed in the tumor (right). 
Table 1 Comparison of dynamic-enhanced CT, conventional power Doppler US, and contrastenhanced power Doppler US in the evaluation of blood flow signals of HCC according to the tumor size

\begin{tabular}{rcccc} 
Size $(\mathrm{mm})$ & Number of lesions & $\begin{array}{c}\text { Blood flow detection } \\
\text { by dynamic-enhanced } \\
\text { CT }\end{array}$ & $\begin{array}{c}\text { Blood flow detection by } \\
\text { conventional power } \\
\text { Doppler US }\end{array}$ & $\begin{array}{c}\text { Blood flow detection by } \\
\text { contrast-enhanced } \\
\text { power Doppler US }\end{array}$ \\
\hline$\sim 10$ & 2 & $2 / 2(100 \%)$ & $0 / 2(0 \%)$ & $0 / 2(0 \%)$ \\
$11 \sim 15$ & 7 & $6 / 7(85.7 \%)$ & $5 / 7(71.4 \%)$ & $7 / 7(100 \%)$ \\
$16 \sim 20$ & 5 & $4 / 5(80 \%)$ & $2 / 5(40 \%)$ & $4 / 5(80 \%)$ \\
$21 \sim$ & 3 & $2 / 3(66.7 \%)$ & $2 / 3(66.7 \%)$ & $3 / 3(100 \%)$ \\
\hline Total & 17 & $14 / 17(82.4 \%)$ & $9 / 17(52.9 \%)$ & $14 / 17(82.4 \%)$ \\
\hline
\end{tabular}

Table 2 Comparison of dynamic-enhanced CT, conventional power Doppler US, and contrast-enhanced power Doppler US in the evaluation of blood flow signals of HCC according to the tumor location

\begin{tabular}{ccccc}
\hline $\begin{array}{c}\text { Tumor location* } \\
(\mathrm{mm})\end{array}$ & Number of lesions & $\begin{array}{c}\text { Blood flow detection } \\
\text { by dynamic-enhanced } \\
\mathrm{CT}\end{array}$ & $\begin{array}{c}\text { Blood flow detection by } \\
\text { conventional power } \\
\text { Doppler US }\end{array}$ & $\begin{array}{c}\text { Blood flow detection by } \\
\text { contrast-enhanced } \\
\text { power Doppler US }\end{array}$ \\
\hline$\sim 30$ & 4 & $4 / 4(100 \%)$ & $3 / 4(75 \%)$ & $3 / 4(75 \%)$ \\
$31 \sim 50$ & 7 & $6 / 7(85.7 \%)$ & $5 / 7(71.4 \%)$ & $6 / 7(85.7 \%)$ \\
$51 \sim 70$ & 2 & $1 / 2(50 \%)$ & $0 / 2(0 \%)$ & $2 / 2(100 \%)$ \\
$71 \sim$ & 3 & $3 / 4(75 \%)$ & $1 / 4(25 \%)$ & $3 / 4(75 \%)$ \\
\hline Total & 17 & $14 / 17(82.4 \%)$ & $9 / 17(52.9 \%)$ & $14 / 17(82.4 \%)$ \\
\hline
\end{tabular}

* Distance from abdominal wall to the center of the lesions.

討でも，造影剤の併用による検出率の向上が明らかで あった，造影剤併用パワードプラ法で血流シグナルが 検出できない理由としては，心拍動によるアーティフ アクトによって評価できない例が 2 例で，血流シグナ ルが検出できない例が 1 例であった。一方，ダイナミ ック CT にて early enhancementを認める症例は17 例中14例(82.4\%)であり，造影剤併用パワードプラ法 は CT に匹敵する血流検出能を有していると考えられ た. ただ, $10 \mathrm{~mm}$ 以下の腫瘍 2 例においてはダイナ ミック CTでは 2 例とも血流信号が検出されたのに対 し，パワードプラ法では造影剤を併用しても血流は検 出されなかった.ダイナミック CT にて血流が検出さ れない理由としては CT 上 SOL 自体が検出されない 例が 2 例, early enhancement が認められない例が 1 例であった。

次に体表面からの深さと血流検出率との関係につい ても検討を行った(Table 2). 造影剤を使用しないパ
ワードプラ法にて，体表面からの深さが $51 〜 70 \mathrm{~mm}$ で血流検出率は $0 / 2(0 \%), 71 \mathrm{~mm}$ 以上で $1 / 4(25 \%)$ と，深い部位に存在する腫瘍に関して血流検出率が低 かった。しかしながら，造影剤の使用によって，パワ ードプラ法による血流検出率は深さが $51 〜 70 \mathrm{~mm}$ で 2/2(100\%)， $71 \mathrm{~mm}$ 以上で $3 / 4(75 \%)$ と，深部の腫瘍 において血流検出率の向上が認められた.ダイナミッ ク CT では体表面からの深さと血流検出率との間に関 連は認められなかった。

\section{CHPD の有用性の検討}

1. CHPD による血流検出感度向上の検討 大多数の症例において造影剂静注後 10 数秒前後より 血流シグナルの増強が腫瘍及び周囲肝に認められた。 周囲肝における血流シグナルの増強は動脈より始ま り,その後門脈のシグナルが増強した. 肝癌の血流シ グナルは，連続送信による観察では，1例を除いた全 例で動脈相から認められ，拍動性を呈した. 残りの 1 
例は門脈相で流入する血流シグナルを認めた。CHPD の間欠送信による観察では肝癌32結節中 30 結節 (93.8 \%)で血流シグナルが認められた (Table 3). 血流が検 出できない理由としては，心拍動によるアーティファ クトと区別がつかない, 肝癌自体がエコーで描出不可 能，が各 1 例ずつであった。 また，血流シグナルが認 められた30結節中 vascular pattern を呈したものは 16例, diffuse pattern を呈したものは14例であった。 一方，ダイナミックCTで early enhancement を呈 した症例は32結節中25結節 (78.1\%)であった。検出で きない理由としては，早期相で iso density となった 症例が 4 例, low density となった症例が 2 例, 腫瘍 自体が CT で検出不可能な症例が 1 例であった。腫瘍 径別の検討では, CHPD の血流シグナル検出率は, $11 \mathrm{~mm}$ 以上の腫瘍では $100 \%$ であった。また，CHPD の血流パターンは，腫瘍径が大きくなるほど diffuse pattern が多くなる傾向がみられた (Table 3)。 今回 の検討では CHPD による肝癌の血流シグナル検出率
はダイナミック CT を凌駕するものと考えられた。 体表面からの深さと血流検出率との関係についても 検討した (Table 4). 最深の腫瘍は体表面から $9 \mathrm{~cm}$ の部位にあったが，体表面からの深さに関わりなく， CHPDでは良好な血流検出率であった。また, CHPD の血流パターンと体表面からの深さとの間に は明らかな関係は認められなかった。体表面からの深 さとダイナミック CT での血流検出率との間にも明ら かな関係は認められなかった。

2. CHPD の血流パターンと肝癌の病理学的所見との 対比

HCC の分化度を組織学的に検討できた症例は16例 であった. CHPDで vascular pattern を呈する肝癌 症例の分化度は多くが高分化型か，高〜中分化型であ り, diffuse pattern を呈する症例の多くは中分化型 か，中～低分化型であった。分化度を中分化型及びそ れより低分化の低分化群と，中分化型より高分化の高 分化群に分類すると, CHPD の血流シグナルのパ夕

Table 3 Comparison of dynamic-enhanced CT and contrast harmonic power Doppler US in the evaluation of blood flow signals of HCC according to the tumor size

\begin{tabular}{|c|c|c|c|c|c|}
\hline \multirow[b]{2}{*}{ Size (mm) } & \multirow[b]{2}{*}{ Number of lesions } & \multirow{2}{*}{$\begin{array}{l}\text { Blood flow detection by } \\
\text { dynamic-enhanced CT }\end{array}$} & \multicolumn{3}{|c|}{ Contrast harmonic power Doppler US } \\
\hline & & & Blood flow detection & Vascular pattern & Diffuse pattern \\
\hline$\sim 10$ & 4 & $4 / 4(100 \%)$ & $2 / 4(50 \%)$ & 2 & 0 \\
\hline $11 \sim 15$ & 9 & $6 / 9(66.7 \%)$ & $9 / 9(100 \%)$ & 6 & 3 \\
\hline $16 \sim 20$ & 12 & $8 / 12(66.7 \%)$ & $12 / 12(100 \%)$ & 5 & 7 \\
\hline $21 \sim$ & 7 & $7 / 7(100 \%)$ & $7 / 7(100 \%)$ & 3 & 4 \\
\hline Total & 32 & $25 / 32(78.1 \%)$ & $30 / 32(93.8 \%)$ & 16 & 14 \\
\hline
\end{tabular}

Table 4 Comparison of dynamic-enhanced CT and contrast harmonic power Doppler US in the evaluation of blood flow signals of HCC according to the tumor location

\begin{tabular}{|c|c|c|c|c|c|}
\hline \multirow{2}{*}{$\begin{array}{l}\text { Tumor location* } \\
\text { (mm) }\end{array}$} & \multirow[b]{2}{*}{ Number of lesions } & \multirow{2}{*}{$\begin{array}{l}\text { Blood flow detection by } \\
\text { dynamic-enhanced CT }\end{array}$} & \multicolumn{3}{|c|}{ Contrast harmonic power Doppler US } \\
\hline & & & Blood flow detection & Vascular pattern & Diffuse pattern \\
\hline$\sim 30$ & 6 & $5 / 6(83.3 \%)$ & $5 / 6(83.3 \%)$ & 2 & 3 \\
\hline $31 \sim 50$ & 13 & $9 / 13(69.2 \%)$ & $13 / 13(100 \%)$ & 6 & 7 \\
\hline $51 \sim 70$ & 9 & $8 / 9(88.9 \%)$ & $8 / 9(88.9 \%)$ & 6 & 2 \\
\hline $71 \sim$ & 4 & $3 / 4(75 \%)$ & $4 / 4(100 \%)$ & 2 & 2 \\
\hline Total & 32 & $25 / 32(78.1 \%)$ & $30 / 32(93.8 \%)$ & 16 & 14 \\
\hline
\end{tabular}

* Distance from abdominal wall to the center of the lesions. 
Table 5 Relationship between the flow pattern on CHPD image and the differentiation degree of HCC. HCC with vascular pattern on CHPD US was associated with better differentiation degree of the tumor $(p=0.035$, Fisher's exact test)

\begin{tabular}{ccc}
\hline \multirow{2}{*}{ Blood flow pattern } & \multicolumn{2}{c}{ Differentiation degree of HCC } \\
\cline { 2 - 3 } on CHPD & moderate-poor, moderate & well-moderate, well \\
\hline diffuse & 6 & 2 \\
vascular & 1 & 7 \\
\hline
\end{tabular}

ーンと分化度の間には相関関係がみられた $(\mathrm{p}=$ 0.035, Fisher's exact test) (Table 5). ダイナミック CT での early enhancement の所見と肝癌の分化度と の関係も検討した. early enhance を示す肝癌の多く は中分化型肝癌か, それより低分化の肝癌が多く, 逆 に early enhance を呈さない肝癌の多くは高分化型肝 癌が多くみられた。しかしながら統計学的有意差は見 られなかった $(\mathrm{p}=0.084$, Fisher's exact test).

\section{考察}

慢性肝炎，及び肝硬変といつた，いわゆる肝癌の高 危険群に対するスクリーニング検査の普及と画像診断 の進歩に伴って, 肝癌は早期に, 小さい結節として発 見されることが多くなり，それに伴って，それら小肝 癌の血行動態が明らかにされてきた.すなわち, 初期 の高分化型肝癌においては，動脈血流が少なく，まだ 門脈血の供給を受けている hypovascular な状態があ り，腫瘍径の増大，分化度の低下に伴って徐々に動脈 血流が増加してやがて動脈血流のみに栄養される古典 的な肝癌に変化していく1,7,8).しかしながら，これ ら早期の小肝癌においては血流が乏しいために, 超音 波ドプラやダイナミック CT といった従来の非侵襲的 な画像診断では血流評価が困難な症例が多くなってき ている，超音波造影剤は従来の超音波では不可能であ った血流評価を可能にすることを期待して開発されて きた。

従来のパワードプラ法を用いた超音波検査におい て，レボビスト®を使用することによって，肝癌の血 流シグナル検出能は飛躍的に向上した。今回の対象と なった肝癌の多くは径 $20 \mathrm{~mm}$ 以下で, 比較的小さい にもかかわらず，血流シグナル検出率は造影剂使用前 が52.9\%であったものが，造影剤の使用によって 82.4 \%と劇的に向上した。従来のパワードプラ法での血流
検出率は久保らの報告9)によると，1 cm 以下で $25 \%$, $1.1-1.5 \mathrm{~cm}$ で56\%，1.6-2.0 cm で74\%，2.1-2.5 $\mathrm{cm}$ で $88 \% ， 2.6 \mathrm{~cm}$ 以上では $100 \%$ であたと記して いる. 我々の造影剤を使用しないパワードプラ法での 検討もこれとほぼ同じと考えられる。これが造影剤の 投与によってさらに感度が向上し，ダイナミック CT (検出率 $82.4 \%)$ と同様の結果であった. したがって, 超音波造影剤は従来のパワードプラ法に使用しても十 分その効果を発揮し，血流検出感度向上に寄与するも のと考えられた。田中ら10) は肝癌に対してカラード プラ法にレボビストを用い, 特に体表面より $7 \mathrm{~cm}$ 以 上深い部位にある血流シグナルの検出率が向上して肝 癌の鑑別診断に有用であったと報告している．今回の 検討でも，造影剤併用によって深い部位での血流検出 能は大きく改善した。本来パワードプラ法はカラード プラ法よりも血流検出能は高い9,11)ため, 造影剤使用 によってパワードプラ法の有用性はさらに高まると考 えられる。

一方，CHPD では肝癌症例において 30/32(93.8\%) において血流シグナルを得ることが可能であり, ダイ ナミック CTを凌駕する成績であると考えられた．体 表面からの深さに関しては, $7 \mathrm{~cm}$ より深い腫場(最大 $9 \mathrm{~cm})$ でもすべて血流シグナルが検出された．従来の パワードプラ法の欠点であった，深部での血流シグナ ル検出率の低下は大幅に改善されたと考えられる。

CHPD を肝癌症例に施行した報告はいくつかみら れる. Wilson ら12) は超音波造影剤として Optisonを 使用し，間欠送信にて腫瘍が着色された球状にみえた と報告しているが，これは我々の diffuse pattern に 相当するものと思われる. vascular patternのような 記述はみられない.ただし彼らの対象は 2.8 から 13.5 $\mathrm{cm}$ の大きさの肝癌であり, ほとんどが hypervas- 
cular な古典的肝癌であると考えられる。一方, Hosten ら13) はレボビスト®を使用して CHPD を行い, 腫 瘍血管からの血流シグナルを点状, 短い線状, 長い線 状に分類しており，線状の血流シグナルは我々の vascular pattern に相当する所見と思われる，肝癌の サイズについては記述がないが，間欠送信は行ってお らず，そのためか我々の diffuse pattern に対応する ような所見は得られていない. 本邦の造影ハーモニッ ク超音波の報告では, pulse inversion harmonic imaging 法14)や coded harmonic angio 15) 法などを使 用して gray scale 表示を行ったものがあり，腫颤の 血流シグナルの表現として腫瘍血管と腫瘍の濃染， あ るいは実質の染影14,15)などの記述がみられる．今回 の我々の報告での CHPD の vascular pattern は腫瘍 血管に相当するものと考えられる. diffuse pattern は 腫瘍実質の濃染あるいは染影とほほ一致するものと考 えられる。ただ，CHPD は空間分解能に劣り，本来 の血管よりもカラーシグナルがはみだして表現されて しまうというパワードプラ法の欠点は克服されていな い.そのため，間欠送信において腫崵実質の enhance が出現してきた際に腫崵血管と腫瘍実質の濃染との区 別がつかずに，腫瘍がびまん性に血流シグナルで占め られるという状態を呈するため，今回の検討では diffuse pattern と表現した.

今回の検討では，この血流パターン分類は肝癌の分 化度と密接に関係していることが明らかとなった。 $\mathrm{CO}_{2}$ 動注 US アンギオグラフィーの検討にて, 肝癌は 高分化型から中分化型に脱分化するにつれて動脈血流 が増加してくることが報告されており7,8), 我々の結 果はこれと一致するものと考えられる。このような造 影剤併用超音波検査の血流パターンと肝癌の組織学的 所見の対応を認めた報告は今回の我々の報告が初めて であると思われる。

早期の小型肝癌においてはダイナミック CT MRI などの非侵襲的な画像診断では確定診断がつか ないことがしばしばみられる。その場合は digital subtraction angiography, 経動脈性門脈造影下 CT (CT-AP)や， $\mathrm{CO}_{2}$ 動注 US アンギオグラフィーなど, 侵襲的な画像検査を行って血流動態を把握して質的診 断をつけることが行われる16)。ここに, CHPD の出 現によって, 肝癌における非侵襲的な画像検査として 有力なものがひとつ加わったということができる。さ らに, CHPD は高い血流シグナル検出能により, 肝 癌の治療効果判定にも応用できる可能性を秘めてお
り，今後のさらなる検討が待たれるものである.

\section{結 論}

パワードプラ法に造影剤を使用することによって明 らかに血流シグナルの検出感度が向上し，ダイナミッ ク CT と同等の結果であった．特に体深部での検出率 が向上し，造影剤は有用であると考えられた。CHPD の肝癌に抢ける血流シグナル検出の感度はダイナミッ ク CT 以上であった。また CHPDにおいて，肝癌の 血流パターンは分化度と密接に関係し, vascular pattern を呈するものは高分化の肝癌に多くみられた。 CHPD は原発性肝癌の診断に有用であることを示唆 する結果であった。

この報告の一部は第4回日本肝臟学会大会 (DDW Japan 2000)に扔いて 2000 年10月25日に「造影剂併用超音波パワ ードプラ法の肝癌診療における有用性について」と題して 発表した。

\section{文献}

1）枝光 理：肝細胞癌腫瘍血管に関する病理学的 研究一主に血管数について一。肝蔵 $33: 15-$ 18,1992

2) Hosoki $T$, Mitomo M, Choi S, et al: Visualization of tumor vessels in hepatocellular carcinoma. Acta Radiologica 38 : 422-427, 1997

3) Burns PN, Wilson SR, Muradali D, et al: Microbubble destruction is the origin of harmonic signals from FS069. Radiology 201 (p) : 158-159, 1996

4) Burns PN, Fritzsch $T$, Weitschies $W$, et al : Pseudo-Doppler shifts from stationary tissue due to the stimulated emission of ultarasound from a new microsphere contrast agent. Radiol. ogy $197(\mathrm{p}): 402,1995$

5) Calliada F, Compani R, Bottinelli $\mathrm{O}$, et al : Ultrasound contrast agents. Basic principles. Eur J Radiol. 27 : S157-S160, 1998

6) Goldberg BB, Liu J, Burns PN, et al: Galactose-based intravenous sonographic contrast agent : Experimental studies. J Ultrasound Med. 12:463-470, 1993

7）工藤正俊, 冨田周介, 樫田博史, 他：肝硬変に伴 う結節性病変の腫瘍内血流動態 一癌化の進展と 血流動態の変化との関連について一. 日消誌 $88: 1554-1565,1991$

8）工藤正俊，富田周介，栃尾人司，他：小肝細胞癌 
の動脈性 vascularity と組織所見: $\mathrm{CO}_{2}$ 動注 US angiography および切除標本による検討. 肝臓 26:1008-1016, 1991

9）久保裕史, 堀口祐爾, 今井英夫, 他：肝細胞癌の 血流評価におけるパワードプラ法の有用性に関す る検討. J Med Ultrasonics, 26, 939-947

10) Tanaka S, Kitamura T, Yoshioka F, et al : Effectiveness of galactose-based intravenous contrast medium on color Doppler sonography of deeply located hepatocellular carcinoma. Ultrasound in Med. \& Biol. 21:157-160, 1995

11) Koito K, Namiedo $T$, Morita $K$ : Differential Diagnosis of small hepatocellular carcinoma and adenomatous hyperplasia with power Doppler sonography. AJR $170: 157-161,1998$

12) Wilson SR, Burns PN, Muradali D, et al: Harmonic hepatic US with microbubble contrast agent. Initial experimence showing improved characterization of hemangioma, he- patocellular carcinoma, and metastasis. Radiology $215: 153-161,2000$

13) Hosten N, Puls R, Lemke AJ, et al : Contrastenhanced power Doppler sonography: Improved detection of characteristic flow patterns in focal liver lesions. J Clin Ultrasound. $27: 107-115,1999$

14）原 浩二, 沼田和司, 田中克明, 他：進行肝細胞 癌の診断：Contrast-Enhanced Harmonic GrayScale Image (CHGI) と Helical CT, US Angiographyとの比較. J Med Ultrasonics, 27, $1239-1246,2000$

15）前川清, 大谷真由美, 文艶玲, 他: Coded Harmonic Angioによる肝腫瘍の血行動態的パ ターン分類の試み. J Med Ultrasonics, 28, J485，2001

16）池田健次：小型肝細胞癌の画像による質的診断. 「肝細胞癌の予知・診断・治療」メディカルレビ ュー社, 大阪, 1999, p77-82

\title{
Evaluation of contrast-enhanced ultrasonography in the diagnosis of hepatocellular carcinoma
}

\author{
Kunio Suzuki, Moritoshi Yamamoto, Nobuhiro Shirahata, Nao Kurashige \\ Osamu Nishiyama, Keiichi Arai, Yukinori Yamada, Toshifumi Ito \\ Eiji Masuda, Harumasa Yoshinara, Takenobu Kamada
}

The authors evaluated the practical value of intravenous sonographic contrast agent, Levovist ${ }^{\circledR}$, in the diagnosis of hepatocellular carcinoma (HCC) by ultrasound. In the first study, 17 nodules of hepatocellular carcinoma (HCC) were studied by power Doppler sonography. After Levovist ${ }^{\circledR}$ injection, the number of lesions with blood flow signal increased from 9 (52.9 $\%)$ to $14(82.4 \%)$. In the next study, a newly developed technique, contrast harmonic power Doppler (CHPD), was used. In 32 nodules of HCC, blood flow was detected in 30 (93.8\%), while it was detected in $25(78.1 \%)$ in dynamic-enhanced CT. HCC could be classified into two groups according to the blood flow pattern in CHPD; one was vascular pattern and the other was diffuse pattern. Tumors with vascular pattern were better differentiated in the histology compared with tumors with diffuse pattern $(\mathrm{p}=0.035)$. Ultrasound with the administration of Levovist ${ }^{\circledR}$ seemed to be a promising diagnostic modality for HCC.

Department of gastroenterology, Osaka Rosai hospital(Osaka) 